\title{
Teaching English by Using Andragogy Approach for EFL Students
}

\author{
Via Armu Manangsa \\ Tadris Bahasa Inggris, IAIN Curup \\ viaarmu05@gmail.com \\ Paidi Gusmuliana \\ Tadris Bahasa Inggris, IAIN Curup \\ paidigusmuliana@iaincurup.ac.id \\ Eka Apriani \\ Tadris Bahasa Inggris, IAIN Curup \\ eka.apriani@iaincurup.ac.id \\ Corresponding email: viaarmu05@gmail.com
}

\begin{abstract}
The purpose of this study was to describe the implementation of andragogy used by English lecturers in learning. This research used descriptive qualitative method. The subjects of this study were 14 English Tadris lecturers. The data were collected using questionnaire through Google Form and analyzed using inferential percentage. There were seven results of the research. First $35.7 \%$ of lecturers always apply discipline and $35.7 \%$ of lecturer motivate students. Second, $28.6 \%$ lecturers always use learning method. Third, $42.9 \%$ lecturers always plan the learning, $42.9 \%$ lecturers encourage students to be independent and $42.9 \%$ lecturers help students connect learning to experience. Fourth, $35.7 \%$ of lecturers always analyze the gap between student goals and performance. Fifth, $57.1 \%$ of lecturers always accept student errors and $50 \%$ of lecturers encourage dialogue between students. Sixth, $57.1 \%$ of lecturers always implement classroom management. Finally, $42.9 \%$ of lecturers provide the best service and $42.9 \%$ of lecturers maintain disciplined classrooms to reduce disruption in learning.
\end{abstract}

Keywords: Teaching English; EFL Students; Andragogy Approach.

\section{Introduction}

Learning is the process of obtaining various kills and attitudes. In human life, learning has begun in the womb until death with a number of stimulation provided by parents, lecturers and people in the environment, even from natural events experienced by humans during life. Therefore, humans cannot be separated from education, because education is a process carried out by each individual towards a better direction. Dealing with human potential, scholars express about studying ranging from swings to burrows. In achieving an educational goal, the position of the teacher or lecturer is important because 
$\mathrm{He}$ is a driving force in the implementation of education. The quality of education is largely determined by the quality of the teacher or lecturer.(Wang \& Storey, 2015).

Character education must have some basic aspects, such as intelligence, creativity, and high discipline (Fathurrochman \& Apriani, 2017). Learning is essentially done by anyone, both children and adult humans. An important aspect of education that receives attention is the concept of education for adults (andragogy). Education or learning efforts in adults require special approaches and strategies and must have a strong grip on the concept of theory based on the assumptions or understanding of adults as students. By using the theories, adult learning activities or efforts within the framework of the development or realization of achieving the ideals of lifelong education can be obtained with the support of theoretical concepts.

In the teaching and learning process, lecturers as educators must have knowledge of approaches for adult students so that students can learn effectively and efficiently based on a theoretical approach that hits the expected goal (Saleh \& Mujiyanto, 2017; Martina, Syafryadin, Saputra, Rakhmanina, 2020). One step to having a strategy is to have to master presentation techniques used in teaching English. The theory of andragogy education proposed by $M$. Knowles can be implemented in every culture. By considering and understanding adults in learning, learning in recruiting adults to have a learning structure will be more effective and productive. Using the andragogy method proposed by $M$. Knowles, adults will learn not as in pedagogy that comes from "content plans", but from "design processes". In the existing education process, adults will discuss in an environment of mutual respect through finding and contributing their knowledge and experiences to other adult students (Taylor, 2009).

$\mathrm{EFL}$ is a place where lecturers teach English to students in countries that used English is not as their first or second language. As we know that in this country, the first language is Mother language and the second is Indonesian language. It made the students in Indonesia difficulties learning English. Thus, it is interesting to be saved more specifically when attracting andragogy of EFL students in the English Study Program. By investigating it, there will be an expectation of obtaining valuable information about how to teach and 
improve the achievement of EFL students. For this reason researchers are interested in conducting a study entitled Teaching English By Using The Andragogy Approach For Efl Students In lain Curup. At the end of this study, the next research will get results related to the andragogy-approved analysis. Then this research can provide valuable information for IAIN Curup.

Andragogy learning systems are used to teach students that have been considered as adults. Therefore andragogy is the form of learning which facilitates the achievement of learning target and trains a student to be independent, able to be a teacher for himself. Knowles and Srinivasan declare that andragogy as the art and science to help adult to learner. According to Knowles there is fundamental differences regarding the assumptions used by andragogy with pedagogy. Andragogy basically uses assumptions of selfconcept, experience, learning readiness, and learning orientation(Pelatihan et al., n.d.). An andragogy approach focuses on adult students. It can be concluded that andragogy is a learning process which can help adults develop ideas and needs. Learning by using the andragogy approach is a normal thing for lecturers to do. However, in reality, the tutor's ability to apply the andragogy approach still needs to be improved(Wang \& Storey, 2015).

Adult Education or andragogy is defined as the art and science of helping adults carry out learning activities (Rahman \& Elshap, 2018). Adult education is a systematic and continuous learning process for someone who has an adult status based on the main characteristics of his social role with the aim of achieving changes in his knowledge, attitudes, values and skills (Rahman \& Elshap, 2018). The approach taken must refer to the concept of adult education (andragogy) which includes the following four things, a. educational material or curriculum must be oriented based on the needs and interests of students (subject matter centered orientation), b. learning orientation is based on solving problems faced by students (problem centered orientation), and c. time perspective becomes important for students. that is, adults learn for the present not for the future, and $d$. subject matter must be adapted to the experiences possessed by students, because basically they are adults who have had experience throughout their lives (Juddah, 2015).

Bryson states that adult education is all educational activities carried out by adults in daily life that only use part of their time and energy to gain 
intellectual enhancements. Here the emphasis is on the use of part of his time and energy (not all of his time and energy) to obtain his intellectual improvement. While Reeves, Fansler, and Houle stated that adult education is an effort aimed at self-development carried out by individuals without legal coercion, without trying to make the main field of activity. Emphasis here is given to business that is not forced, and does not make its main effort(Kompetinsi et al., 2018).

Andragogy requires that adult learners must be involved in identifying their learning needs and planning how those needs can be met. Learning for adults must be active, not passive. The improper application of the andragogy approach will greatly affect the quality of a learning process. With the development of many theories of education it can be realized that education does not only channel knowledge and skills, but understand knowledge, attitudes, and aspects of skills in psychology which are emphasized in an integrated manner. In the learning process lecturers usually apply lecturing method to expose facts and theories, reading assignments, exercises, quizzes, memorization and examinations. According to Dugan Laird andragogy is the study of how adults learn. and Laird believes that every adult learns in a way that is significantly different from the ways in which a child acquires new behavior(Waspodo, 2009).

\section{Research Methodology}

This research was descriptive quantitative. The subject was all English Lecturers at IAIN Curup. The participants are 14 lecturers of IAIN Curup in English Study Program. The survey was aimed at describing the application of andragogy approach in learning English at IAIN Curup. This research is a research that is supported by journals which are implemented with several unapproved stages which have been developed by Victor Wang. Although the writing adopted a research questionnaire from Victor Wang, the author also validated the questionnaire content with several English experts, namely from Raden Fatah Palembang and Bengkulu University. From the results of the validation the questionnaire was declared eligible to be used for this study.

Descriptive studies are designed to obtain the status of current phenomena and are intended to determine the nature of the discussion at the 
time of the study. Sukardi stated that descriptive research was used to clearly discuss the research problem before they went to the study site. This research was designed with a more economical survey. At this time in surveys conducted online more and more researchers are using internet technology. based on the survey instrument sample, the researchers built 34 survey questions issued into a random sample of 14 English language lecturers in the IAIN CURUP Environment. 14 participants filled out the questionnaire by filling in the google form and were sent to researchers.

This research is designed to further study in which applications and uses are centered on students in any setting, especially where lecturers help preadult and adult learning. Since we recognize the difference between children's education and adult education, what is more important is the teacher uses methods that are truly on learning. The design of this study is to determine the general designed mode for lecturers.

To achieve the best learning outcomes, Experts argue that English must support communicative communication or collaborative learning processes on learning. This mode of appreciating andragogy improves communicative movements or collaborative learning processes for students. Participants in this study are English language teachers who teach English in other major programs. The study participants were lecturers and then they focused more on grammar learning. In this study there were 14 out of 15 lecturers in the iain curup environment who had filled in the google form questionnaire containing 34 statements in the instrument used in this study.

The survey instrument consisted of seven factors: Student-Centered Activities, Personalization Instruction, Related Experiences, Assessing Student Needs, Climate Development, Participation in the Learning Process, and Flexibility for Personal Development.

The data was analyzed using percentage formulation. All the questions are positive with five choices and five graded scores as follows:

$$
\begin{aligned}
& \text { Always }=5 \\
& \text { Almost always }=4 \\
& \text { Often }=3 \text { Rarely }=2 \\
& \text { Almost never }=1 \\
& \text { Never }=0
\end{aligned}
$$




\section{Findings and Discussion Findings}

Table 1 is the summary of results of the survey analysis on each of the seven factors of the instrument sample. The average responses of the participants to the results of each of the seven factors have been described in a separate table. Each of the seven factors below contains several items that make up teaching methods that have been centered on instructor dominance. Standard deviation scores are provided for participants which are summarized in the table. The following are the results of this study.

Table 1. Learner-Centered Activities

\begin{tabular}{|c|l|c|}
\hline Number & $\begin{array}{l}\text { FACTOR 1: } \\
\text { Learner-Centered Activities }\end{array}$ & Result \\
\hline 1 & $\begin{array}{l}\text { Lecturers draw a discipline attitude to students in learning. } \\
(35,7 \%)\end{array}$ & $\begin{array}{c}5 \\
(21,4 \%)\end{array}$ \\
\hline 2 & $\begin{array}{l}\text { The lecturer analyzes the students goals in the learning } \\
\text { process. }\end{array}$ & $\begin{array}{c}5 \\
(35,7 \%)\end{array}$ \\
\hline 4 & $\begin{array}{l}\text { The lecturer motivates students in group discussion } \\
\text { activities to classmates. }\end{array}$ & $\begin{array}{l}\text { The lecturer uses something that has been proven by } \\
\text { history that the adult person needs to learn as the } \\
\text { teacher's main criteria for planning the next episode of } \\
\text { learning. }\end{array}$ \\
\hline 5 & $\begin{array}{l}\text { The lecturer uses one basic teaching method because it } \\
\text { has been found that most adults have the same learning } \\
\text { style. }\end{array}$ & - \\
\hline
\end{tabular}

Based on the data in table 1, it can be seen that the percentage of $35.7 \%$ of the lecturers chose that the lecturer draw a discipline attitude to students in learning and $35.7 \%$ of the lecturers chose the lecturer motivates students goals in the learning process. The results of factor 1 in learner-centered activities are that lecturers continue to apply a culture of discipline to maintain classroom stability and the learning process so that students quickly grasp the material that has been designed so that learning runs well. Lecturers also motivate students in group discussions that can improve students' mindset by getting students accustomed to face to face with their classmates so as to create an atmosphere of structured discussion. 
Table 2. Personalizing Instruction Responses

\begin{tabular}{|c|c|c|}
\hline Number & $\begin{array}{l}\text { FACTOR 2: } \\
\text { Personalizing Instruction Responses }\end{array}$ & Result \\
\hline 1 & $\begin{array}{l}\text { Lecturers give senior students more time in completing } \\
\text { their assignments. }\end{array}$ & $\begin{array}{c}1 \\
(7,1 \%)\end{array}$ \\
\hline 2 & $\begin{array}{l}\text { Lecturers use the lecture method in presenting learning } \\
\text { to adult students. }\end{array}$ & $\begin{array}{c}4 \\
(28,6 \%)\end{array}$ \\
\hline 3 & $\begin{array}{l}\text { Lecturers support students to support successful } \\
\text { education to be the main determinant in planning } \\
\text { learning objectives. }\end{array}$ & $\begin{array}{c}1 \\
(7,1 \%)\end{array}$ \\
\hline 4 & $\begin{array}{l}\text { Lecturers give assignments to all students on the same } \\
\text { topic. }\end{array}$ & $\begin{array}{c}1 \\
(7,1 \%)\end{array}$ \\
\hline 5 & $\begin{array}{l}\text { Lecturers use different teaching materials with different } \\
\text { students. }\end{array}$ & 1 \\
\hline
\end{tabular}

Based on the data in table 2, it can be seen that the percentage of $28,6 \%$ of the lecturer chose Lecturers use the lecture method in presenting learning to adult students. In term of Personalizing Instruction Responses, the lecturers are accustomed to using the lecture method in a learning. In adult students it is easy to understand the direction of the lecturer as a reference for someone's independence. Lecturers are able to arouse curiosity to students with the lecture method in delivering material for each meeting.

This lecture method is very effective in encouraging adults to open broad mindsets as provisions for students to be more critical in any case. The objectives are based on this research method with individual abilities. The instructions go alone. However, they only tend to like the lecture method and give the same assignment to a given topic. They did not encourage the search for real life examples as the development of tasks related to real life situations

Table 3. Relating to Experience Responses

\begin{tabular}{|c|c|c|}
\hline Number & $\begin{array}{l}\text { FACTOR 3: } \\
\text { Relating to Experience Responses }\end{array}$ & Result \\
\hline 1 & $\begin{array}{l}\text { Lecturer plan learning episodes to take into account my } \\
\text { students' prior }\end{array}$ & $\begin{array}{c}6 \\
(42,9 \%)\end{array}$ \\
\hline 2 & $\begin{array}{l}\text { Lecturer plan activities that will encourage each student's } \\
\text { growth from dependence on others to greater } \\
\text { independence. }\end{array}$ & $\begin{array}{c}6 \\
(42,9 \%)\end{array}$ \\
\hline 3 & $\begin{array}{l}\text { Lecturer organize adult learning episodes according to the } \\
\text { problems that my students encounter in everyday life. }\end{array}$ & $\begin{array}{c}2 \\
(14,3 \%)\end{array}$ \\
\hline 4 & Lecturer help students relate new learning to their prior & 6 \\
\hline
\end{tabular}




\begin{tabular}{|c|l|c|}
\hline & experiences. & $(42,9 \%)$ \\
\hline 5 & Lecturer teach units about problems of everyday living. & - \\
\hline
\end{tabular}

Based on the results of the table 3, it can be seen that the percentage of $42.9 \%$ of the lecturers chose the episode of learning as a plan to take into account previous students and $42.9 \%$ the lecturer chose The lecturer plans an activity that will encourage growth in each student from others to greater independence in each individual students. Results from the Relating to Experience factor Responses lecturers always make new designs in learning so that the classroom atmosphere remains in control and not monotonous, still encouraging students to increase high independence by helping students connect new learning to be able to experience that has happened to they. The lecturer always helps them analyze their experiences and connect them with the materials. In order to be relevant learning, learning episodes will be arranged according to the problems determined by students in daily life. Students are asked to always ask questions related to their community.

Table 4. Assessing Student Needs Responses

\begin{tabular}{|c|l|c|}
\hline Number & $\begin{array}{l}\text { FACTOR 4: } \\
\text { Assessing Student Needs Responses }\end{array}$ & Result \\
\hline 1 & $\begin{array}{l}\text { The lecturer assumes achieving student goals with the level of } \\
\text { student achievement. }\end{array}$ & $\begin{array}{c}5 \\
(35,7 \%)\end{array}$ \\
\hline 2 & $\begin{array}{c}\text { The lecturer gives input to students informally. } \\
(7,1 \%)\end{array}$ \\
\hline 3 & $\begin{array}{l}\text { The lecturer has his own agreement to help students analyze } \\
\text { the educational needs of students. }\end{array}$ & - \\
\hline 4 & $\begin{array}{l}\text { Lecturers help students develop short-term and long-term } \\
\text { goals. }\end{array}$ & $\begin{array}{c}2 \\
(14,3 \%)\end{array}$ \\
\hline
\end{tabular}

Based on the data in table 5, it can be seen that the percentage of $35,7 \%$ of the lecturer chose that The lecturer assumes achieving student goals with the level of student achievement. Result of Assessing Student Needs Responses states that lecturers are able to encourage students in analyzing student goals in learning such as, students must know that what their goals are and achieve each learning needed by students and encourage students to improve their current performance in order to achieve a high level of performance in a learning. Lecturers treat students as adults and try to find what adults want and need to be known by every student. Individual meetings 
and informal counseling are their mainstays on learning. They diagnose the gap between student goals and student performance levels. They help students in developing long-term goals.

Table 5. Climate Building Responses

\begin{tabular}{|c|l|c|}
\hline Number & $\begin{array}{l}\text { FACTOR 5: } \\
\text { Climate Building Responses }\end{array}$ & Result \\
\hline 1 & Lecturer encourages dialogue among my students. & $\begin{array}{c}7 \\
(50 \%)\end{array}$ \\
\hline 2 & $\begin{array}{l}\text { Lecturer utilizes the many competencies that most adults } \\
\text { already possess to achieve educational objectives. }\end{array}$ & $\begin{array}{c}3 \\
(21,4 \%)\end{array}$ \\
\hline 3 & $\begin{array}{l}\text { Lecturer accepts errors as a natural part of the learning } \\
\text { process. }\end{array}$ & $\begin{array}{c}8 \\
(57,1 \%)\end{array}$ \\
\hline 4 & $\begin{array}{l}\text { Lecturer allows my students to take periodic breaks during } \\
\text { class. }\end{array}$ & $\begin{array}{c}2 \\
(14,3 \%)\end{array}$ \\
\hline 5 & $\begin{array}{l}\text { Lecturer designs activities that build students' self-esteem and } \\
\text { sense of accomplishment while delivering course content. }\end{array}$ & $\begin{array}{c}5 \\
(35,7 \%)\end{array}$ \\
\hline
\end{tabular}

Based on the data in table above, it can be seen that the percentage of $50 \%$ of the lecturer chose that lecturer encourage dialogue among my students and $57,1 \%$ of the lecturer chose Lecturer accept errors as a natural part of the learning process. The results of the Climate Building Responses that in a learning process students make mistakes, when the lecturer receives well the natural learning process. However, the lecturer strives to always be open for students to think and produce their own thoughts.

Dialogue and interaction with other students is highly recommended during learning. Barriers are removed by using various competencies that students already have as building poles for educational purposes. Risk taking is supported by accepting student mistakes as a natural part of the learning process. Students can experiment and explore elements related to their selfconcept and practice interpersonal skills. Failure serves as a feedback tool to direct positive learning in the future.

Table 6. Participation in the Learning Process

\begin{tabular}{|c|l|c|}
\hline Number & $\begin{array}{l}\text { FACTOR 6: } \\
\text { Participation in the Learning Process }\end{array}$ & Result \\
\hline 1 & $\begin{array}{l}\text { Lecturers allow students to participate in developing the } \\
\text { criteria for evaluating their performance in class. }\end{array}$ & 5 \\
\hline
\end{tabular}




\begin{tabular}{|c|l|c|}
\hline 2 & $\begin{array}{l}\text { Lecturer arranges the classroom so that it is easy for students } \\
\text { to interact. }\end{array}$ & $\begin{array}{c}8 \\
(57,1 \%)\end{array}$ \\
\hline 3 & $\begin{array}{l}\text { Lecturers allow students to participate in making decisions } \\
\text { about the topics that will be covered in class. }\end{array}$ & $\begin{array}{c}3 \\
(21,4 \%)\end{array}$ \\
\hline 4 & $\begin{array}{l}\text { Lecturers have my students identify problems that they wish } \\
\text { to solve. }\end{array}$ & $\begin{array}{c}4 \\
(28,6 \%)\end{array}$ \\
\hline 5 & $\begin{array}{l}\text { Lecturer uses learning contracts when assessing adult } \\
\text { students' learning. }\end{array}$ & $\begin{array}{c}4 \\
(28,6 \%)\end{array}$ \\
\hline
\end{tabular}

Based on the table 6, it can be seen that the percentage of $57,1 \%$ of the choice of the achievement of a learning, in this case the lecturer always arranges the class so that the learning process remains stable and comfortable for students to interact in learning. When students feel comfortable, learning will easily make students capture the material delivered by the lecturer.

Table 7. Flexibility for Personal Development Responses

\begin{tabular}{|c|l|c|}
\hline Number & $\begin{array}{l}\text { FACTOR 7: } \\
\text { Flexibility for Personal Development Responses }\end{array}$ & Result \\
\hline 1 & $\begin{array}{l}\text { Lecturer provides knowledge rather than serve as a } \\
\text { resource person. }\end{array}$ & $\begin{array}{c}6 \\
(42,9 \%)\end{array}$ \\
\hline 2 & $\begin{array}{l}\text { Lecturer sticks to the instructional objectives that Lecturer } \\
\text { writes at the beginning of a program. }\end{array}$ & $\begin{array}{c}5 \\
(35,7 \%)\end{array}$ \\
\hline 3 & $\begin{array}{l}\text { Lecturer maintains a well-disciplined classroom to reduce } \\
\text { interference to learning. }\end{array}$ & $\begin{array}{c}6 \\
(42,9 \%)\end{array}$ \\
\hline 4 & $\begin{array}{l}\text { Lecturer avoids discussion of controversial subjects that } \\
\text { involve value judgments. }\end{array}$ & $\begin{array}{c}(14,3 \%) \\
-\end{array}$ \\
\hline 5 & $\begin{array}{l}\text { Lecturer avoids issues that relate to the student's concept } \\
\text { of himself or herself. }\end{array}$ & - \\
\hline
\end{tabular}

Based on the table 7, it can be seen that the percentage of $42.6 \%$ of the choices of the majority of lecturers are lecturers who provide knowledge to students rather than being resource persons and $42.6 \%$ of lecturers maintain classrooms from disruption due to undisciplined learning. The results of the Flexibility for Personal Development Responses that every lecturer always provides knowledge in the learning process, so that learning can run well, the attitude of discipline must continue to run to reduce a disruption in learning. They set goals for students at the beginning of the program and obey them regardless of the oddities that might arise from different student needs. Disciplined classrooms are seen as a stimulus for learning. 


\begin{tabular}{|c|c|c|c|}
\hline Number & ASPECT & RESULT & PERCENTAGE \\
\hline \multirow[t]{2}{*}{1} & \multirow{2}{*}{$\begin{array}{l}\text { FACTOR 1 } \\
\text { Learner- } \\
\text { Centered } \\
\text { Activities }\end{array}$} & $\begin{array}{l}\text { Lecturer uses appropriate forms of } \\
\text { disciplinary action when it is } \\
\text { needed. }\end{array}$ & $35,7 \%$ \\
\hline & & $\begin{array}{l}\text { Lecturer tries to motivate students } \\
\text { by confronting them during group } \\
\text { discussions with their classmates. }\end{array}$ & $35,7 \%$ \\
\hline 2 & $\begin{array}{l}\text { FACTOR } 2 \\
\text { Personalizing } \\
\text { Instruction } \\
\text { Responses }\end{array}$ & $\begin{array}{l}\text { Lecturer uses lecturing as the best } \\
\text { method of presenting my subject } \\
\text { material to adult students. }\end{array}$ & $28,6 \%$ \\
\hline \multirow[t]{3}{*}{3} & \multirow{3}{*}{$\begin{array}{l}\text { FACTOR } 3 \\
\text { Relating to } \\
\text { Experience } \\
\text { Responses }\end{array}$} & $\begin{array}{l}\text { Lecturer plans learning episodes } \\
\text { to take into account my students' } \\
\text { prior }\end{array}$ & $42,9 \%$ \\
\hline & & $\begin{array}{l}\text { Lecturer plans activities that will } \\
\text { encourage each student's } \\
\text { growth from dependence on } \\
\text { others to greater independence. }\end{array}$ & $42,9 \%$ \\
\hline & & $\begin{array}{l}\text { Lecturer helps students relate new } \\
\text { learning to their prior experiences. }\end{array}$ & $42,9 \%$ \\
\hline 4 & $\begin{array}{l}\text { FACTOR } 4 \\
\text { Assessing } \\
\text { Student Needs } \\
\text { Responses }\end{array}$ & $\begin{array}{l}\text { Lecturer helps students diagnose } \\
\text { the gaps between their goals and } \\
\text { their present level of } \\
\text { performance. }\end{array}$ & $35,7 \%$ \\
\hline \multirow[t]{2}{*}{5} & \multirow[t]{2}{*}{$\begin{array}{l}\text { FACTOR } 5 \\
\text { Climate Building } \\
\text { Responses }\end{array}$} & $\begin{array}{l}\text { Lecturer accepts errors as a } \\
\text { natural part of the learning } \\
\text { process. }\end{array}$ & $57,1 \%$ \\
\hline & & $\begin{array}{l}\text { Lecturer encourages dialogue } \\
\text { among my students. }\end{array}$ & $50 \%$ \\
\hline 6 & $\begin{array}{l}\text { FACTOR } 6 \\
\text { Participation in } \\
\text { the Learning } \\
\text { Process }\end{array}$ & $\begin{array}{l}\text { Lecturer arranges the classroom } \\
\text { so that it is easy for students to } \\
\text { interact. }\end{array}$ & $57,1 \%$ \\
\hline \multirow[t]{2}{*}{7} & \multirow{2}{*}{$\begin{array}{l}\text { FACTOR } 7 \\
\text { Flexibility for } \\
\text { Personal } \\
\text { Development } \\
\text { Responses }\end{array}$} & $\begin{array}{l}\text { Lecturer provide knowledge } \\
\text { rather than serve as a resource } \\
\text { person. }\end{array}$ & $42,9 \%$ \\
\hline & & $\begin{array}{l}\text { Lecturer maintains a well- } \\
\text { disciplined classroom to reduce } \\
\text { interference to learning. }\end{array}$ & $42,9 \%$ \\
\hline
\end{tabular}

\section{Discussion}

The application of andragogy approach to EFL students includes the following activities: lecturers apply discipline, lecturers motivate students in learning, lecturers use lectures in learning, lecturers plan new activities to increase student morale, lecturers help analyze student experiences with learning, lecturers accept students' mistakes in various the learning process and 
encourages students to dialogue in the learning process, the lecturer helps students in creating an atmosphere to be comfortable interacting, and the lecturer maintains discipline to stay awake from distractions. There were seven discussion of the research.

First, there were seven factor that become a reference in implementing andragogy learning at IAIN Curup. The lecturer used the appropriate form of disciplinary action when needed with a percentage of $35.7 \%$. In accordance with Rogers's opinion which states that education also addresses changes in behavior, which is in accordance with adult learning(Mustofa Kamil, 2001). And then with the percentage of $35.7 \%$ most choices of answers with the statement that the lecturer tries to motivate students by confronting them during group discussions with their classmates and in accordance with Cercone's theory which cites the opinions of Merriam and Caffarela by presenting the assumption that that adults have motivation intrinsic learning is greater than extrinsic learning motivation (Umriyah et al., 2012). The andragogy model assumes people adults tend to be more motivated towards learning that can help them solve problems in life or generate internal satisfaction. This does not mean that external motivation has no relevance, but the need for internal motivation is more interesting. Students have confidence in themselves that learning outcomes can be utilized in life. The process and results of learning can improve the quality of life(Shafi Laili Dewi Nur Latifah, 2019).

Second, the most choices with a percentage of $42.9 \%$ with the lecturer statement using the best method for presenting my subject matter to adult students. in line with the statement on the results of research in the journal of Refreshing lecturing: a guide for lecturers that Lectures are the most common teaching methods everywhere so they are an important part of the teacher list. Lectures are at least as effective as other teaching methods in providing information and explaining. Intention, transmission and output are the basis of the lecture model (Brown \& Manogue, 2001).

Third, the lecturer plan learning episodes to take into account my students' prior with a percentage of $42.9 \%$ and Lecturer plan activities that will encourage each student's growth from dependence on others to greater independence with percentage $42,9 \%$. This choice is in line with Knowles's work which states that, andragogy was initially based on four assumptions as a 
contradiction with the traditional pedagogical model centered on leturers. The four initial assumptions are: 1. Self-direction 2. Experience-based 3. Readiness to learn 4. Orientation for learning (Saleh \& Mujiyanto, 2017).

Fourth, Lecturer help students diagnose the gaps between their goals and their present level of performance with a percentage of $35.7 \%$ for the most choices in factor 4 is almost the same as the statement on the 1983 EEQ Kristian research findings that Lecturers must provide opportunities for students to learn with their own way. The lecturer must state the purpose of learning at the beginning of the lesson(Saleh \& Mujiyanto, 2017). And also in line with the principle of Knowles, namely Diagnosing learning needs. One basic way to involve adults in planning involves the following two-step process. First, the desired competencies or learning outcomes are identified, and second, the difference between the desired competencies and the student's current abilities is noted. The result is a self-assessment of what the student wants to learn (Clardy, 2005).

Fifth, Lecturers encourage dialogue among students with a percentage of $50 \%$. Supported by theories from Merriam et al. Stated that learning is the result of the construction of meaning and how people understand their experiences. Social constructivists believe that knowledge is "constructed" when people collaborate on shared problems or tasks. Implications for adult learning include the idea that self-direction is a constructionist view. Cognitive internships, situated learning, reflective practice, and community practice are ideas found in adult learning and constructivist literature (Saleh \& Mujiyanto, 2017).

Sixth, Lecturer arranges the classroom so that it is easy for students to interact according to Christian Eoq in a revised and modified study consisting of 50 points. One of them is in line with the choice of a lecturer in IAIN Curup to steep in every lesson, namely: lecturer must create a teaching situation that makes students actively participate. In this case the curbed IAIN lecturer has applied the theory of andragogy to teaching (Saleh \& Mujiyanto, 2017).

Seventh, with a percentage of $42.9 \%$ with the statement that the lecturer maintains a disciplined classroom to reduce disruption in learning. With the Docking theory which states the ability of individuals to discipline themselves or in other words self-control by disciplining themselves displayed in their attitudes 
and behavior towards others and their environment with acceptable limits of behavior must enable the campus environment to function as a community that fosters harmony and humanity in order to create an environment conducive to serious and uninterrupted learning (Blandford, 2003).

The results of this study refer to the Knowles assumption which states that: Humans during growth and development must gain experience. It will never run out as long as humans are still alive. Experience will develop as the times develop. Every human being has the potential that must be developed through the learning process. In using the theory of andragogy approach many lecturers have used the andragogy approach in the application of learning for adults with aspects that have been listed as indicators of andragogy theory.

\section{Conclusion and Suggestion}

From the explanation above, it be concluded that lecturers in other areas have not yet fully applied the andragogy approach in each learning process. Lecturers only apply a number of factors that they often apply to lessons. Thus the application of andragogy in the English study program has not been maximized.

This research is to study and determine learning in the learning system by fostering a student's sense of independence in learning. Andragogy's advice is very well designed to help mature students achieve their goals by learning more effectively that is practiced by lecturers on the Tadris Bahasa Inggris lecture method and is suitable according to andragogy aspects namely: the lecturer creates ecstasy and disciplinary atmosphere that supports the independent learning process. Lecturers make new plans in learning that have been diagnosed in special learning needs, assist student experience in the learning process and in analyzing experiences with learning. Then the results that can be concluded from this study are that English study program lecturers have most of the aspects of andragogy in adult student learning in the IAIN Curup environment.

\section{References}

Blandford, s. (2003). Managing discipline in schools. Routledge.

Botkin, J.W., Dkk. (2014). No Limits To Learning. Journal of Transformative Education 12 (2), 134-47. https://doi.org/10.1177/1541344614548589. 
Brown, G., \& Manogue, M. (2001). AMEE medical education guide: Refreshing lecturing: A guide for lecturer. Medical Teacher. 23(3), 231-244. https://doi.org/10.1080/01421590120043000

Clardy, A. (2005). Andragogy adult learning and education its best. https://eric.ed.gov/?id=ED492132.

Fathurrochman, I., \& Apriani, E. (2017). Pendidikan karakter perspektif prendidikan islam dalam upaya deradikalisasi paham radikal. POTENSIA: Jurnal Kependidikan Islam. 3(1), 122-142

Martina, F., Syafryadin., Saputra, J. , Rakhmanina, L. (2020). Novice teacher's pedagogical content knowledge (pck) in teaching English for young learners. Journal of Critical Reviews. 7(14), 1475.

Kamil, M. (2001). ANDRAGOGY. 36(1), 1-48.

Rahman, A., \& Elshap, D. . (2018). Implementasi Kekuatan Motivasi Belajar dalam Pendekatan Andragogi. Jurnal Empowerment, 5(2), 1-12 https://doi.org/10.22460/empowerment.v5i2pl-12.548

Saleh, M., \& Mujiyanto, J. (2017). Andragogy and pedagogy: Learning method orientations for EFL adult learners. Asian Journal of Educational Research. 5(2), 32-41. www.multidisciplinaryjournals.com

Shafi, M. V. R. (2019). Penerapan pendekatan andragogi pada pembelajaran private class untuk membentuk keterampilan berbicara di lkp professional broadcasting school surabaya. Journal of Chemical Information and Modeling, $53(9)$,

1689-1699. https://doi.org/10.1017/CBO9781 107415324.004

Sukardi. (2008). Metodologi penelitian pendidikan: Kompetisi dan praktiknya, Jakarta: Bumi Aksara.

Nurchinta, A., \& Tandyonomanu, D. (2015). Penerapan model pembelajaran andragogi untuk meningkatkan hasil mata diklat pemetaan keluarga sejahtera di bidang pelatihan dan pengembangan BKKBN Provinsi Jawa Timur. Jurnal Mahasiswa Teknologi Pendidikan. 6(2), 1-10.

Tasir, Z., and Norah, N. (2008). A survey on online teaching preference among pre- service teachers in Malaysia: Andragogy vs Pedagogy. 1022-1027.

Umriyah, M., Yulianto, A., \& Hindarto, N. (2012). Penggunaan bahan ajar dengan pedekatan Andragogy sebagai upaya peningkatan kreativitas dan hasil belajar siswa SMA RSBI. Jurnal Pendidikan Fisika Indonesia. 8(1), 68-73

Wang, V.C.X., \& Storey, V.A. (2015). Andragogy and teaching english as a foreign language in China. Journal the Reference Librarian. 56 (4), 295-314.

Waspodo, M. (2009). Peran tutor dalam pembelajaran dengan pendekatan Andragogy. Jurnal Ilmiah VISI PTK-PNF. 4(1), 63-70. 